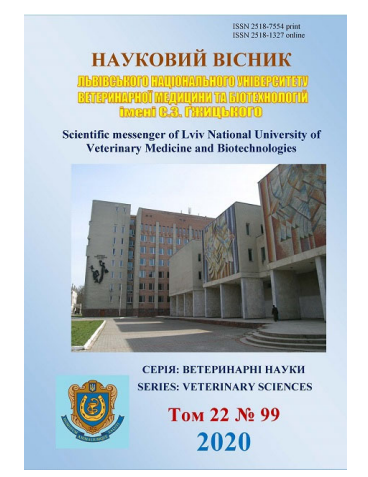

\author{
Науковий вісник Аьвівського національного університету \\ ветеринарної медицини та біотехнологій імені С.3. Гжицького. \\ Серія: Ветеринарні науки \\ Scientific Messenger of Lviv National University \\ of Veterinary Medicine and Biotechnologies. \\ Series: Veterinary sciences
}

\title{
The content of total protein and protein fractions in cows during pregnancy and their diagnostic value
}

\author{
Ya. S. Stravsky ${ }^{1}$, N. P. Boltyk ${ }^{2}$, R. M. Sachuk ${ }^{3}$, V. I. Serheyev ${ }^{3}$, T. M. Rushchynska ${ }^{2}$ \\ ${ }^{1}$ I. Horbachevsky Ternopil National Medical University, Ternopil, Ukraine \\ ${ }^{2}$ Ternopil Research Station IBM NAAS, Ternopil, Ukraine \\ ${ }^{3}$ Rivne State University for the Humanities, Rivne, Ukraine
}

\section{Article info}

Received 21.09.2020

Received in revised form 19.10.2020

Accepted 20.10.2020

I. Horbachevsky Ternopil National Medical University, 1, Freedom Square, Ternopil, 46001, Ukraine E-mail:stravskyy@tdmu.edu.ua

Ternopil Research Station IBM NAAS, Trolleybusna Str., 12,

Ternopil, 46002, Ukraine.

Rivne State University for the Humanities, Plastova Str., 29-a Rivne, 33028, Ukraine. $T e l:+38-097-671-90-63$ E-mail: sachuk.08@ukr.net
Stravsky, Ya. S., Boltyk, N. P., Sachuk, R. M., Serheyev, V. I., \& Rushchynska, T. M. (2020). The content of total protein and protein fractions in cows during pregnancy and their diagnostic value. Scientific Messenger of Lviv National University of Veterinary Medicine and Biotechnologies. Series: Veterinary sciences, 22(99), 198-202. doi: 10.32718/nvlvet9930

The aim of the article was to study the content of total protein and protein fractions in the blood of cows during pregnancy and determine their diagnostic value. The studies were performed as follows. Within 7 days after insemination on the principle of analogues selected a group of 100 cows. Pregnancy was diagnosed by rectal examination of cows 60 days after insemination. In experimental animals, starting from the 25 th to the 29th day after insemination, blood samples for morphological and biochemical studies were taken monthly before delivery. The total protein content in the serum was determined by the biuret reaction, protein fractions - nephelometric method. Depending on the course of labor and the postpartum period, cows were divided into two groups. The first group included 30 animals with a physiological course of the postpartum period. The second group was formed of 30 cows with subinvolution of the uterus. According to this goal, the dynamics of total protein, albumin, alpha-, beta- and gammaglobulins in the blood of cows with physiological course of pregnancy and prone to the development of subinvolution of the uterus from the first to 9 months of pregnancy. It was found that in clinically healthy cows the onset of pregnancy is characterized by a high (0.89) albumin-globulin ratio, which in the fourth month of pregnancy decreases to 0.78 , in the fifth or sixth months increases to 0.85 , followed by a decrease to 0.78 before childbirth. In cows prone to uterine subinvolution, a significant difference in albumin content was found in the first month of pregnancy $(47.07 \pm 1.21 \mathrm{vs} .41 .02 \pm 1.26 \%$ ). In the third to fifth months of pregnancy, there was an increase in the proportion of albumin in the protein to $44.62 \pm 0.88 \%$ and a new decrease in the seventh to ninth months to $41.96 \pm 0.3 \%$. In the first month of pregnancy, the albumin-globulin ratio was 0.7 , with a tendency to increase in the fifth to sixth months of pregnancy to 0.8 , and decrease to 0.72 before calving. Analyzing the dynamics of alpha-globulins in clinically healthy cows, we noted two peaks of decrease in their percentage in the third month of pregnancy (from $16.02 \pm 0.08$ to $15.14 \pm 0.06 \%$ ) and in the fifth month, $96 \pm 0.48 \%$ ) and a consistent increase in the seventh to ninth months of pregnancy (up to $17.22 \pm 0.13 \%$ ). And in cows prone to the development of uterine subinvolution, with a slightly higher percentage at the beginning of pregnancy $(16.02 \pm 0.08$ to $17.08 \pm 0.05 \%)$, we did not notice significant changes in the percentage of this globulin, except for a significant increase in seventh to ninth month of pregnancy (up to $18.01 \pm 0.24-$ $19.01 \pm 0.32 \%)$. It is proposed to use the albumin-globulin ratio at 6, 7, 8, 9 months of gestation as a prognostic factor in the detection of cows prone to uterine subinvolution.

Key words: pregnancy, protein, albumins, globulins, uterine subinvolution.

\section{Вміст загального протеїну і протеїнових фракцій у корів у період тільності та їх діагностична значимість}

Я. С. Стравський${ }^{1}$, Н. П. Болтик ${ }^{2}$, Р. М. Сачук ${ }^{3}$, В. І. Сергеєв ${ }^{3}$, Т. М. Рущинська 
${ }^{1}$ Тернопільський начіональний медичний університет імені I. Я. Горбачевського, м. Тернопіль, Украӥна

${ }^{2}$ Тернопільска дослідна станиія ІВМ НААН, м. Тернопіль, Україна

${ }^{3}$ Рівненський державний гуманітарний університет, м. Рівне, Украӥна

Метою статті стало дослідження вмісту загального протеїну і протеїнових фракиій у крові корів у період тільності та визначення їх діагностичної значимості. Дослідження проводилися наступним чином. Протягом 7 днів після осіменіння за принципом аналогів відібрали групу з 100 корів. Діагностику тільності проводили шляхом ректального дослідження корів через 60 днів після осіменіння. У піддослідних тварин, починаючи з 25- 29-го дня після осіменіння, цимісячно до родів відбирали проби крові для морфологічних та біохімічних досліджень. Загальний вміст протеїнів у сироватці крові визначали за біуретовою реакцією, протеїнові фракиії-нефелометричним методом. Залежно від перебігу родів і післяродового періоду корів розділяли на дві групи. До першої групи увійшли 30 тварин з фізіологічним перебігом післяродового періоду. Друга група була сформована з 30 корів із субінволюиією матки. Відповідно поставленій меті висвітлено динаміку загального протеїну, альбумінів, альфа-, бета- та гаммаглобулінів у крові корів з фізіологічним перебігом тільності та схильних до розвитку субінволючиї матки з периого до 9 місяців тільності. Встановлено, щзо у клінічно здорових корів початок тільності характеризується високим $(0,89)$ альбуміно-глобуліновим коефіцієнтом, який на четвертому місяці тільності знижується до 0,78, на п'ятому-шостому місяцях підвищується до 0,85, з наступним зниженням до 0,78 перед отелом. У корів, схильних до субінволюиії матки, встановлено достовірну різницю вмісту альбумінів уже на першому місяиі тільності (47,07 \pm 1,21 проти 41,02 \pm 1,26\%). На третьому-п'ятому місяиях тільності спостерігали підвищення частки альбумінів у складі білків до 44,62 \pm 0,88 \% i нове зниження на сьомому-дев'ятому місяиях до 41,96 $\pm 0,3 \%$. На першому місяці тільності альбуміно-глобуліновий коефіцієнт становив 0,7, з тенденцією до зростання на п'ятому-шостому місячях тільності до 0,8, та зниженням до 0,72 перед отелом. Аналізуючи динаміку альфа-глобулінів у клінічно здорових корів, ми

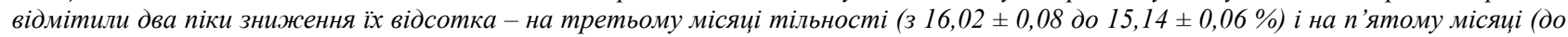
$14,96 \pm 0,48 \%$ ) та послідовне підвищення на сьомому-дев'ятому місіиях тільності (до 17,22 \pm 0,13 \%). А у корів, схильних до роз-

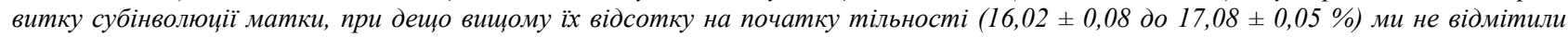
істотних змін відсотка иього глобуліну, за винятком достовірного підвищення на сьомому-дев'ятому місяиі тільності (до

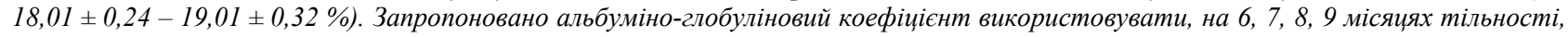
у якості прогностичного при виявленні корів схильних до розвитку субінволючій матки.

Ключові слова: тільність, білок, альбуміни, глобуліни, субінволюція матки.

\section{Вступ}

Сучасна діагностика має у своєму розпорядженні численні методи, які дозволяють швидко і точно визначити стан організму (Lenec, 1989; Borshch et al., 2020; Mazur et al., 2020). Нові технології ведення тваринництва вимагають від лікаря ветеринарної медицини глибоких знань норми і патології окремих систем і організму в цілому, що, у кінцевому результаті, дає можливість зробити правильний висновок про стан здоров'я тварини (Kejik \& Maskova, 1989; Malinowski \& Kaczmarowski, 2003; Klosova et al., 2019). Нині діагностується багато захворювань, які раніше зустрічались рідко, або, маючи спільний етіологічний зв'язок, стали наслідком інших захворювань (Kondrahin, 1998; Temnyi, 2005; Kondrahin, 2005; Kulyaba et al., 2019; Grymak et al., 2020).

Біохімічний контроль за станом речовин і здоров'я тільних корів рекомендують проводити за 2-3 тижні до розтелу; найбільш інформативними показниками при цьому є концентрація загального білка, гаммаглобулінів, холестеролу, бета-ліпопротеїдів, вітамінів A i C (Temnyi, 2005).

Поряд 3 цим, робіт присвячених дослідженню показників крові корів з моменту запліднення до розтелу мало.

Mema - дослідити вміст загального білка і білкових фракцій у крові корів у період тільності та визначити їх діагностичну значимість.

\section{Матеріал і методи досліджень}

Протягом 7 днів після осіменіння за принципом аналогів відібрали групу з 100 корів. Діагностику тільності проводили шляхом ректального досліджен- ня корів через 60 днів після осіменіння. У піддослідних тварин, починаючи з 25-29-го дня після осіменіння, щомісячно до родів відбирали проби крові для морфологічних та біохімічних досліджень.

Загальний вміст протеїнів у сироватці крові визначали за біуретовою реакцією, білкові фракції - нефелометричним методом (Kondrahin et al., 2004).

Залежно від перебігу родів і післяродового періоду корів розділяли на дві групи. До першої групи увійшли 30 тварин з фізіологічним перебігом післяродового періоду. Друга група була сформована 330 корів із субінволюцією матки.

Результати досліджень обробляли статистично (Lakin, 1990; Kucherenko et al., 2001) з використанням програми Microsoft Excel 2003. Оцінку вірогідності здійснювали за критерієм Стьюдента, а результати середніх значень вважали статистично вірогідними при $\mathrm{P} \leq 0,05 ; \mathrm{P} \leq 0,01$ та $\mathrm{P} \leq 0,001$.

\section{Результати та їх обговорення}

Білки є основною і найбільш важливою структурною частиною живих організмів. Саме розуміння життя і його головні критерії (прояви, форми) - ріст, рух, розмноження, обмін речовин - тісно пов'язані $з$ білковими структурами організму. Характерною рисою протеїнів $є$ висока лабільність, на яку поряд 3 рівнем годівлі, істотний вплив має вік тварин, її продуктивність, фізіологічний стан, а також пора року.

Проведені нами дослідження свідчать (табл. 1), що у клінічно здорових корів, на другому-третьому місяцях тільності спостерігається незначне зменшення в сироватці крові загального протеїну (з 82,10 $\pm 0,90$ до $80,16 \pm 1,16$ г/л) з подальшою стабілізацією впродовж 
четвертого-восьмого місяців і достовірним зниженням (до 77,37 \pm 1,22 г/л) на дев'ятому місяці.

У корів, схильних до субінволюції матки, при дещо нижчому вмісті протеїну на початку вагітності $(82,10 \pm 0,90$ і 78,10 $\pm 1,40$ г/л) спостерігалася подібна динаміка, але $з$ меншим рівнем стабільності. В кінці тільності різниця вмісту протеїну між групами зростала i на 9-му місяці була високо вірогідною $(77,37 \pm 1,22$ і $73,43 \pm 1,03$ г/л).

Зменшення кількості загального протеїнну відбулося в першу чергу за рахунок зменшення вмісту альбумінів. Так особливо це помітно у клінічно здо- рових корів на другому місяці $(47,07 \pm 1,21$ i $45,31 \pm 0,79 \%)$, на сьомому і дев'ятому місяцях тільності коли відсоток альбумінів знизився до $43,95 \pm 0,27 \%$.

У корів, схильних до субінволюції матки, перш за все встановлено достовірну різницю вмісту альбумінів уже на першому місяці тільності $(47,07 \pm 1,21$ проти 41,02 \pm 1,26 \%). По друге, на третьому-п’ятому місяцях тільності спостерігали підвищення частки альбумінів у складі білків до 44,62 $\pm 0,88 \%$ i нове зниження на сьомому-дев'ятому місяцях до $41,96 \pm 0,3 \%$.

\section{Таблиця 1}

Динаміка вмісту загального білка і білкових фракцій у крові корів впродовж вагітності, $\mathrm{M} \pm \mathrm{m}, \mathrm{n}=30$

\begin{tabular}{|c|c|c|c|c|c|}
\hline \multirow{3}{*}{$\begin{array}{c}\text { Місяці } \\
\text { вагітності }\end{array}$} & \multirow{3}{*}{$\begin{array}{c}\text { Загальний протеїн, } \\
\text { г/л }\end{array}$} & \multicolumn{4}{|c|}{ Протеїнові фракції, у \% } \\
\hline & & \multirow{2}{*}{ альбуміни } & \multicolumn{3}{|c|}{ глобуліни } \\
\hline & & & альфа- & бета- & гамма- \\
\hline \multirow{2}{*}{1} & $82,10 \pm 1,90$ & $47,07 \pm 1,21$ & $16,02 \pm 0,08$ & $11,31 \pm 0,59$ & $25,61 \pm 1,36$ \\
\hline & $\overline{78,10 \pm 1,40^{*}}$ & $\overline{41,10 \pm 1,26^{* *}}$ & $\overline{17,08 \pm 0,05^{*}}$ & $\overline{12,21 \pm 0,91^{*}}$ & $\overline{29,71 \pm 1,04^{*}}$ \\
\hline \multirow{2}{*}{2} & $81,10 \pm 1,25$ & $45,31 \pm 0,79$ & $16,34 \pm 0,09$ & $12,11 \pm 0,06$ & $26,25 \pm 0,13$ \\
\hline & $\overline{77,41 \pm 1,14^{*}}$ & $\overline{41,44 \pm 0,52^{* *}}$ & $\overline{17,01 \pm 0,04^{*}}$ & $\overline{13,21 \pm 0,06^{*}}$ & $28,34 \pm 0,07^{* *}$ \\
\hline \multirow{2}{*}{3} & $80,16 \pm 1,16$ & $47,81 \pm 1,13$ & $15,14 \pm 0,06$ & $10,12 \pm 0,12$ & $26,93 \pm 0,56$ \\
\hline & $\overline{78,31 \pm 1,39}$ & $\overline{43,18 \pm 1,12^{* *}}$ & $\overline{17,06 \pm 0,04^{* *}}$ & $\overline{12,41 \pm 0,13^{* *}}$ & $\overline{27,35 \pm 0,48}$ \\
\hline \multirow[b]{2}{*}{4} & $80,11 \pm 1,14$ & $45,04 \pm 0,39$ & $15,66 \pm 0,05$ & $11,91 \pm 0,17$ & $27,18 \pm 0,98$ \\
\hline & $\overline{77,06 \pm 1,01^{*}}$ & $\overline{43,92 \pm 0,96}$ & $\overline{17,76 \pm 0.61^{* *}}$ & $\overline{12,12 \pm 0,16}$ & $\overline{26,41 \pm 0,60}$ \\
\hline \multirow{2}{*}{5} & $81,91 \pm 0,49$ & $46,06 \pm 0,79$ & $14,96 \pm 0,48$ & $13,36 \pm 0,28$ & $25,52 \pm 0,21$ \\
\hline & $\overline{80,31 \pm 0,69}$ & $\overline{44,62 \pm 0,88}$ & $\overline{17,16 \pm 0,51^{* *}}$ & $\overline{14,01 \pm 0,14^{*}}$ & $24,31 \pm 0,31^{*}$ \\
\hline \multirow{2}{*}{6} & $80,82 \pm 1,11$ & $46,01 \pm 0,46$ & $15,01 \pm 0,21$ & $13,56 \pm 0,30$ & $25,42 \pm 0,47$ \\
\hline & $\overline{78,01 \pm 1,31^{*}}$ & $\overline{44,32 \pm 0,86^{*}}$ & $\overline{17,66 \pm 0,34^{* *}}$ & $\overline{14,56 \pm 0,26^{*}}$ & $\overline{24,46 \pm 0,66}$ \\
\hline \multirow{2}{*}{7} & $80,61 \pm 1,05$ & $45,38 \pm 0,51$ & $15,93 \pm 0,22$ & $13,86 \pm 0,74$ & $25,01 \pm 0,17$ \\
\hline & $\overline{77,82 \pm 1,03^{*}}$ & $\overline{43,87 \pm 0,41^{*}}$ & $\overline{18,01 \pm 0,24^{* * *}}$ & $\overline{14,97 \pm 0,85}$ & $24,02 \pm 0,22^{*}$ \\
\hline \multirow[b]{2}{*}{8} & $79,20 \pm 1,03$ & $44,04 \pm 0,43$ & $16,52 \pm 0,15$ & $14,20 \pm 0,35$ & $24,64 \pm 0,21$ \\
\hline & $\overline{76,32 \pm 1,21^{*}}$ & $\overline{42,68 \pm 0,25^{*}}$ & $\overline{18,62 \pm 0,25^{* *}}$ & $\overline{15,80 \pm 0,27^{* *}}$ & $23,50 \pm 0,27^{*}$ \\
\hline \multirow[b]{2}{*}{9} & $77,37 \pm 1,22$ & $43,95 \pm 0,27$ & $17,22 \pm 0,23$ & $15,36 \pm 0,40$ & $23,47 \pm 0,20$ \\
\hline & $\overline{73,43 \pm 1,03^{* * *}}$ & $\overline{41,96 \pm 0,32^{*}}$ & $\overline{19,01 \pm 0,32^{* *}}$ & $\overline{16,20 \pm 0,32^{*}}$ & $22,83 \pm 0,18^{*}$ \\
\hline
\end{tabular}

Примітка: чисельник - 1 група; знаменник - 2 група; ${ }^{*} \mathrm{P} \leq 0,05 ;{ }^{* *} \mathrm{P} \leq 0,01 ;{ }^{* * *} \mathrm{P} \leq 0,001$ у порівнянні другої групи корів до першої групи

Аналізуючи динаміку альфа-глобулінів у клінічно здорових корів, ми відмітили два піки зниження їх відсотка - на третьому місяці тільності (з 16,02 $\pm 0,08$ до $15,14 \pm 0,06 \%$ ) і на п’ятому місяці (до $14,96 \pm 0,48 \%$ ) та послідовне підвищення на сьомомудев'ятому місіцях тільності (до 17,22 \pm 0,13\%). А у корів, схильних до розвитку субінволюції матки, при дещо вищому їх відсотку на початку тільності $(16,02 \pm 0,08$ до $17,08 \pm 0,05 \%)$ ми не відмітили істотних змін відсотка цього глобуліну, за винятком достовірного підвищення на сьомому-дев'ятому місяці тільності (до 18,01 \pm 0,24 - 19,01 $\pm 0,32 \%$ ).

Частка бета-глобулінів у складі білкових фракцій у клінічно здорових корів піддавалася зниженню на другому-третьому місяцях тільності, тоді зростала на четвертому-п'ятому місяцях, далі дещо стабілізувалася і знову підвищувалася на восьмому-дев'ятому місяцях, тоді як у корів, схильних до субінволюції матки спостерігалися також підвищення долі фракції на другому, п’ятому і в кінці тільності, відповідними зниженнями між ними.

Нарешті відсоток гамма-глобулінів у складі протеїну клінічно здорових корів був значно нижчим ніж у схильних до субінволюції матки $(25,61 \pm 1,36$ i $29,71 \pm 1,04 \%$ ). Впродовж тільності в його динаміці виділяли періоди підвищення - на другомучетвертому місяцях, до $27,18 \pm 0,98 \% 3$ подальшим зниженням аж до кінця вагітності до 23,47 $\pm 0,20 \%$. У динаміці фракції гамма-глобулінів корів, схильних до субінволюції матки, при значно вищому “стартовому“ рівні відмічено їх зниження до 24,31 $\pm 0,31 \%$ на п'ятому місяці тільності з наступною стабілізацією і кінцевим зниженням в кінці тільності до $23,83 \pm 0,18 \%$.

Як показано на нижченаведеному рисунку 1 початок тільності у клінічно здорових корів характеризувався високим $(0,89)$ альбуміно-глобуліновим коефіцієнтом, який не був стабільним і вже на четвертому місяці тільності знижувався до 0,78. На п'ятому- 
шостому місяцях тільності цей показник підвищувався до 0,85 , а у наступних місяцях знижувався до 0,78 .

У корів, схильних до субінволюції матки, тільність розпочиналася із достовірно нижчим $(0,7)$ альбуміноглобуліновим коефіцієнтом, який помісячно зростав і виявився найвищим на п’ятому-шостому місяцях тільності - 0,8, що відповідало нижній межі норми. У наступних місяцях тільності А/Г коефіцієнт знижувався аж до отелу до 0,72.

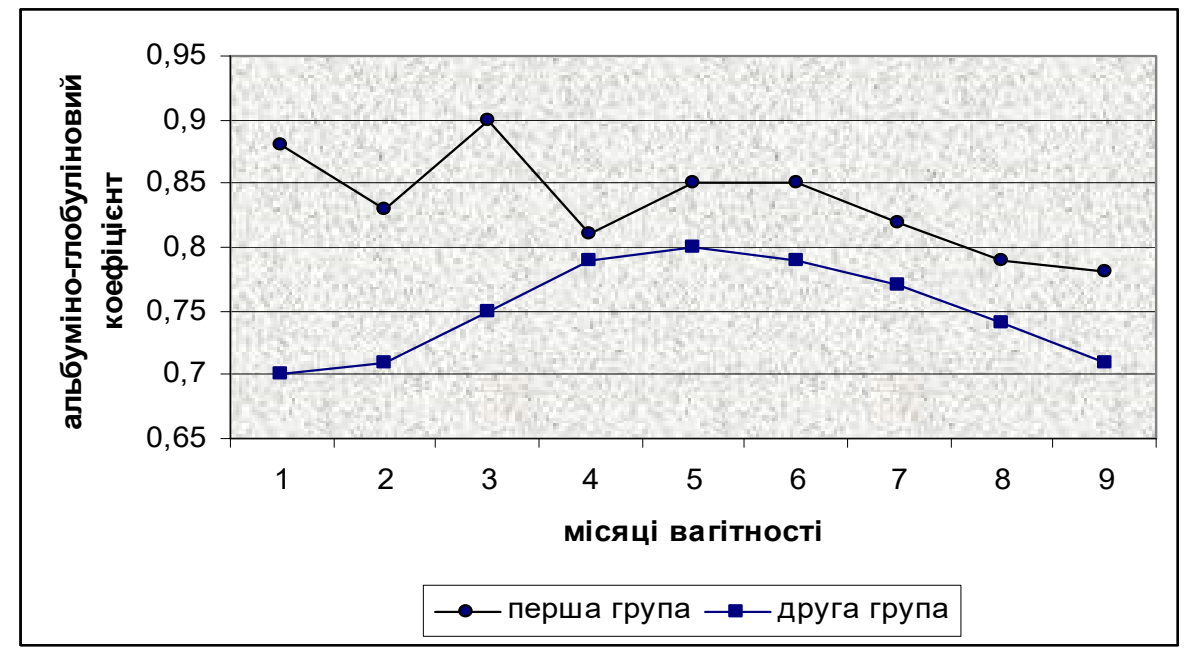

Рис. 1. Динаміка альбуміно-глобулінового коефіцієнта корів у період вагітності, $\mathrm{n}=30$

\section{Висновки}

1. У клінічно здорових корів початок тільності характеризується високим $(0,89)$ альбуміноглобуліновим коефіцієнтом, який на четвертому місяці тільності знижується до 0,78 , на п'ятому-шостому місяцях підвищується до $0,85,3$ наступним зниженням до 0,78 перед отелом.

2. У корів, схильних до субінволюції матки, на першому місяці тільності альбуміно-глобуліновий коефіцієнт був 0,7, 3 тенденцією до зростання на п’ятому-шостому місяцях тільності до 0,8 , та зниженням до 0,72 перед отелом.

3. Альбуміно-глобуліновий коефіцієнт можна використовувати, на 6, 7, 8, 9 місяцях тільності, у якості прогностичного при виявленні корів схильних до розвитку субінволюції матки.

\section{References}

Borshch, O. O., Gutyj, B. V., Sobolev, O. I., Borshch, O. V., Ruban, S. Yu., Bilkevich, V. V., Dutka, V. R., Chernenko, O. M., Zhelavskyi, M. M., \& Nahirniak, T. (2020). Adaptation strategy of different cow genotypes to the voluntary milking system. Ukrainian Journal of Ecology, 10(1), 145-150. doi: 10.15421/2020 23.

Grymak, Y., Skoromna, O., Stadnytska, O., Sobolev, O., Gutyj, B., Shalovylo, S., Hachak, Y., Grabovska, O., Bushueva, I., Denys, G., Hudyma, V., Pakholkiv, N., Jarochovich, I., Nahirniak, T., Pavliv, O., Farionik, T., \& Bratyuk, V. (2020). Influence of "Thireomagnile" and "Thyrioton" preparations on the antioxidant status of pregnant cows. Ukrainian Journal of Ecology, 10(1), 122-126. doi: 10.15421/2020 19.

Kejik, C., \& Maskova, A. (1989). Termovizni mereni povrchovych teplot vemen vprubehu strojnio dojeni. Zemed techn, 4, 305-307.
Klosova, X. G., Bushueva, I. V., Parchenko, V. V., Shcherbyna, R. O., Samura, T. O., Gubenko, I. Ya., Gutyj, B. V., \& Khariv, I. I. (2019). Trifuzol Suppositories Usage Results On The Course Of Endometrial Inflammatory Processes In Cows. Research Journal of Pharmaceutical, Biological and Chemical Sciences, 10(1), 1215-1223. URL: https://www.rjpbcs.com/pdf/ 2019 10(1)/[157].pdf.

Kondrahīn, I. P. (1998). Polimorbidnost' vnutrennej patologii. Visnik Bilocerkivs'kogo derzhavnogo agrarnogo universitetu, 5(1), 79-83 (in Russian).

Kondrahin, I. P. (2005). Izuchenie sochetannyh vnutrennih boleznej zhivotnyh prioritetnoe nauchnoe napravlenie. Veterinarija, 1, 44-48 (in Russian).

Kondrahin, I. P., Arhipov, A. V., \& Lechenko, V. I. (2004). Metody veterinarnoj klinicheskoj laboratornoj diagnostiki. M.: KolosS (in Russian).

Kucherenko, M. Ie., Babeniuk, Yu. D., \& Voibitskyi, V. M. (2001). Suchasni metody biokhimichnykh doslidzhen. K.: Fitosotsiotsentr (in Ukrainian).

Kulyaba, O., Stybel, V., Gutyj, B., Turko, I., Peleno, R., Turko, Ya., Golovach, P., Vishchur, V., Prijma, O., Mazur, I., Dutka, V., Todoriuk, V., Golub, O. Dmytriv, O., Oseredchuk, R. (2019). Effect of experimental fascioliasis on the protein synthesis function of cow liver. Ukrainian Journal of Ecology, 9(4), 612-615. URL: https://www.ujecology.com/abstract/effect-ofexperimental-fascioliasis-on-the-protein-synthesisfunction-of-cow-liver-44972.html.

Lakin, G. F. (1990). Biometrija. M.: Vyssh. shk. (in Russian).

Lenec, I. A. (1989). Diagnostika nezaraznyh boleznej zhivotnyh s primeneniem vychislitel'noj tehniki. M.: Agropromizdat (in Russian).

Malinowski, E., \& Kaczmarowski, M. (2003). Zatrzymanie lozyska u krow. Med. Veter., 59(5), 378-381. 
Mazur, N. P., Fedorovych, V. V., Fedorovych, E. I., Fedorovych, O. V., Bodnar, P. V., Gutyj, B. V., Kuziv, M. I., Kuziv, N. M., Orikhivskyi, T. V., Grabovska, O. S., Denys, H. H., Stakhiv, N. P., Hudyma, V. Yu., \& Pakholkiv, N. I. (2020). Effect of morphological and biochemical blood composition on milk yield in Sim- mental breed cows of different production types. Ukrainian Journal of Ecology, 10(2), 61-67. doi: $10.15421 / 2020110$.

Temnyi, M. (2005). Polietiolohichna prychyna neplidnosti koriv - realnist sohodennia. Veterynarna medytsyna Ukrainy, 9, 27-28 (in Ukrainian). 